Vol. 24, No. 1, Januari 2021, hlm. 80-88

\title{
Pengembangan Produk Interior dan Pemasaran bagi UKM Kerajinan Rotan di Kelurahan Rappocini Kota Makassar
}

\author{
${ }^{1}$ Siti Fuadillah A Amin, ${ }^{2}$ Khilda Whildana Nur, ${ }^{3}$ Citra Amalia Amal \\ Fakultas Teknik, Universitas Muhammadiayah Makassar \\ email: ${ }^{1}$ sitifuadillah@unismuh.ac.id
}

\section{Article Info}

Submitted: 23 July 2020

Revised: 5 August 2020

Accepted: 31 August 2020

Published: 12 December 2020

Keywords: UKM, Rattan Crafts, Design Development, Marketing
Kata Kunci : UKM, Kerajinan Rotan,Pengembangan Desain, Pemasaran

\section{Abstract}

UKM is small and medium enterprises, in Indonesia it is one of the strongest drivers of the people's economy. It is said to be tough because it is a business that initially started with small capital but can grow rapidly. UKM in the city of Makassar develops with the holding of Lorong Business Entity activities which are essentially for the welfare of the community. Of the many UKM that have developed in the city of Makassar, one of the existing UKM is the UKM Kerajinan Rotan which makes interior products such as tables, chairs, partitions and the like. The problem faced by the Rattan Handicraft UKM is the lack of business capital which results in a lack of production and human resources regarding product innovation so that socialization is needed to provide insight into the development of rattan handicrafts. Another problem is in terms of promotion and marketing which only uses conventional methods, namely direct purchases or only distributing to several shops in the city of Makassar. The solution offered in PKM activities is in the form of training on how to improve the design and finishing of a rattan handicraft and the like. Through this training, it is hoped that the human resources possessed will experience an increase in the skills of the second solution in terms of product marketing, namely the creation of social media that can help these rattan handicraft SMEs in terms of promotion and marketing so that they can reach consumers outside the Makassar City area. The activity is carried out in three stages, namely presentations, demonstrations, and hands-on practice by participants so that they have their own experience in marketing their handicrafts. After the activity takes place, the monitoring and evaluation process is still carried out to ensure that the results of the activities can provide benefits for partners.

\section{Abstrak}

UKM adalah Usaha Kecil dan Menengah, di Indonesia merupakan salah satu penggerak perekonomian rakyat yang tangguh. Dikatakan tangguh karena merupakan usaha yang awalnya dimulai dengan modal yang kecil tetapi dapat berkembang pesat. UKM di kota Makassar 
berkembang dengan diadakannya kegiatan Badan Usaha Lorong yang pada hakikatnya untuk kesejahteraan masyarakat. Dari sekian banyak UKM yang berkembang di kota makassar, salah satu UKM yang ada yaitu UKM Kerajinan Rotanyang membuat produkinterior seperti meja, kursi, partisi, dan sejenisnya. Permasalahan yang dihadapi UKM Kerajinan Rotan ini adalah minimnya modal usaha yang berakibat pada jumlah produksi serta sumber daya manusia tentang inovasi produk yang kurang sehingga perlu sosialisasi untuk memberikan wawasan tentang perkembangan kerajinan rotan. Permasalahan lain adalah dari segi promosi dan pemasaran yang hanya menggunakan cara konvensional yaitu pembelian secara langsung atau hanya menyalurkan ke beberapa toko di kota Makassar. Solusi yang ditawarkan dalam kegiatan PKM berupa pelatihan mengenai tata cara peningkatan desain maupun finishing suatu kerajinan rotan dan sejenisnya. Melalui pelatihan ini, diharapkan SDM yang dimiliki mengalami peningkatan keterampilan solusi kedua dari segi pemasaran produk, yaitu Pembuatan media sosial yang dapat membantu UKM Kerajinan Rotan ini dalam hal promosi dan pemasaran sehingga bisa menjangkau konsumen di luar wilayah Kota Makassar. Kegiatan dilaksanakan dalam tiga tahap, yaitu presentasi, demonstrasi, dan praktik langsung oleh peserta agar memiliki pengalaman sendiri dalam memasarkan hasil kerajinan mereka. Setelah kegiatan berlangsung, proses monitoring, dan evaluasi tetap dilakukan untuk menjaga agar hasil kegiatan dapat memberikan manfaat untuk mitra.

\section{PENDAHULUAN}

Usaha Kecil dan Menengah atau UKM adalah istilah yang mengacu ke jenis usaha kecil. Menurut Keputusan Presiden RI No. 99 tahun 1998 pengertian Usaha Kecil adalah: "Kegiatan ekonomi rakyat yang berskala kecil dengan bidang usaha yang secara mayoritas merupakan kegiatan usaha kecil dan perlu dilindungi untuk mencegah dari persaingan usaha yang tidak sehat". Usaha Mikro, Kecil dan Menengah (UMKM) di berbagai negara termasuk di Indonesia merupakan salah satu penggerak perekonomian rakyat yang tangguh. Hal ini karena kebanyakan para pengusaha mikro, kecil, dan menengah berangkat dari industri keluarga atau rumahan (Wati, 2011).

Keberadaan UKM di Indonesia sebagian besar fokus pada industri berbasis pertanian (agroindustri). Kemampuan UKM dalam menyerap tenaga kerja dan meningkatkan nilai tambah semakin tinggi. Pada tahun 2009, nilai tambahyang dihasilkan UKM di Indonesiasebesar 2.993.151 Milyar dan jumlah UKM mencapai 52.7 juta atau $99,9 \%$ dari total perusahaan yang ada di Indonesia. Dalam hal menciptakan pekerjaan, UKM di Indoensia mampu menyediakan 96.2 juta tenaga kerja atau $97.3 \%$ dari total tenaga kerja (Kuswantoro, dkk, 2012). Indonesia merupakan pengekspor bahan baku rotan terbesar di dunia. Bahan baku rotan ini di dapat dari luar Pulau Jawa, Menurut release Biro umum dan Humas Departemen perindustrian. Salah satu produk UKM agroindustri adalah kerajinan rotan (Departemen Perdagangan, 2008).

Di kota Makassar saat ini pemerintah tengah mencanangkan program BULo yaitu Badan Usaha Lorong di mana program ini merupakan program unggulan pemerintah kota (Pemkot) yang pada hakikatnya untuk kesejahteraan masyarakat terutama masyarakat kecil dan menengah. BULo dibentuk oleh masyarakat lorang yang melibatkan 55 lorong yang tersebar di 11 Kelurahan di Kecamatan Rappocini Kota Makassar. Kecamatan Rappocini merupakan salah satu dari 14 Kecamatan di Kota Makassar dengan luas wilayah $9,23 \mathrm{~km}^{2}$ (Badan Pusat Statistik Kota Makassar, 2019). Sehingga diharapkan dengan adanya program 
ini dapat membantu perekonomian masyrakat. Di kelurahan Rappocini terdapat banyak UKM di lorong yang dikelola masyarakat baik berupa UKM kuliner, maupun UKM Kerajinan. Salah Satu nya UKM Kerajinan Rotan yang dirintis oleh Pak Alex Lapasila. Industri Rotan menjadi salah satu komoditas besar di Indonesia untuk ekspor-impor yang bernilai tinggi dibandingkan dengan kayu. Hal ini disebabkan karena rotan lebih ringan, kuat, lentur, dan murah (Candra \& Darmastuti, 2019).

UKM Kerajinan Rotan di kota Makassar hanya terdapat 2 pengrajin salah satunya yang terdapat di kelurahan Rappocini Kecamatan Rappocini. UKM Kerajinan rotan ini menerima jasa pembuatan produk interior seperti kursi, meja, ayunan bayi, hiasan, dan lain sebagainya yang berbahan baku rotan. UKM ini pun menerima jasa perbaikan kerajinan rotan yang rusak. UKM Kerajinan Rotan ini berdiri sejak tahun 2000, dengan memperkerjakan pegawai 4 orang dari yang membuat rangka hingga menganyam rotan. UKM ini terletak di Jalan Rappocini Raya Lorong 5, Kelurahan Rappocini, Kecamatan Rappocini, Kota Makassar. Mereka menerima pesanan dari café maupun hotel untuk kursi dan juga disaat lebaran UKM rotan ini menerima pesanan untuk tempat parsel.

Persoalan utama yang dihadapi UKM ini adalah masalah modal usaha dan juga produksi yaitu terbatasnya produksi dari segi modal sehingga Tim Pengusul menilai kerajinan rotan yang dibuat oleh UKM ini perlu meningkatkan mutu maupun inovasi dari kerajinan rotan yang mereka buat sehingga pendapatan bisa lebih meningkatdengan cara mengikuti perkembangan yang ada. Seperti dari segi desain, finishing dengan memberikan warna sehingga tidak tergerus dengan kerajinan rotan sintetis yang marak sekarang, tetapi tidak menghilangkan ciri khas dari rotan tersebut. Ataupun memadukan bahan lain dari kerajinan rotan ini. Sehingga solusi nya perlu di berikan pelatihan peningkatan mutu kerajinan rotan. Kerajinan Rotan merupakan salah satu usaha kecil rumah tangga informal dengan memanfaatkan hasil rotan yang tumbuh di daerah tempat tinggal penduduk menjadi suatu produk yang memiliki nilai jual tinggi serta memberikan sentuhan seni yang menarik pada setiap produk yang dihasilkan. Setiap usaha menginginkan hasil produksi yang lebih maksimal dengan keterbatasan sumber daya yang dimiliki (Muhartini dan Kurniati, 2013).

Permasalahan yang dihadapi UKM rotan yaitu mencakup aspek produksi, Sumber Daya Manusia (SDM), serta pemasaran, di mana segi produksi dan Sumber Daya Manusia (SDM) yaitu kurang variatif dari segi desain dan finishing karena tidak mengikuti perkembangan trend dan tidak memiliki sumberdaya yang dapat meningkatkan hal tersebut. Segi pemasaran masih lemahnya market intelligence, mengakibatkan terbatasnya informasi pasar dan salah satu strategi pengembangan pemasaran peningkatan kemampuan market intelligence, dengan mengoptimalkan fungsi atperindag (Kementerian Perindustrian RI, 2019). Pemasaran produk hanya terbatas pada pembeli dari kalangan masyarakat di Kota Makassar dan sekitarnya, karena sistem penjualan masih bersifat konvensional yaitu pembelian langsung di tempat ataupun menyalurkan dibeberapa toko di Kota Makassar. Kelemahan pada proses pemasaran (marketing) ini karena sifatnya hanya menunggu pembeli yang lewat ataupun pemasaran dari mulut ke mulut, ini jelas kurang menguntungkan dalam proses penjualan barang hasil produksi kerajinan rotan. Dengan menggunakan kemajuan teknologi saat ini, penjualan dan pemasaran produk mampu menjangkau seluruh wilayah yang ada di Indonesia.

Solusi yang ditawarkan adalah melalui pelatihan mengenai tata cara peningkatan desain maupun finishing dari kerajinan rotan. Pelatihan ini memperlihatkan desain yang berkembang saat ini dengan model yang lebih modern menggunakan bahan tidak hanya rotan tetapi memakai material lain. Selain desain pelatihan ini memperlihatkan finishing berupa warna yang menarik yang tidak kalah dengan kerajinan rotan sintetis yang merebak akhirakhir ini. Begitu juga dengan pemasaran solusi yang kami tawarkan dari pengabdian kepada masyarakat adalah pelatihan pembuatan dan penggunaan media sosial sebagai media pemasaran yang dapat membantu meningkatkan pemasaran dan penjualan. Tujuan dan manfaat dari pengabdian untuk menjawab permasalahan dari aspek produksi, Sumber Daya Manusia 
(SDM) dan pemasaran yang dihadapi oleh UKM Kerajinan Rotan, diharapkan dengan kegiatan ini Sumber Daya Manusia yang dimiliki mengalami peningkatan keterampilan.dan pemasaran dari penjualan meningkat dengan adanya pembuatan media sosial sebagai media pemasaran kerajinan rotan.

\section{METODE}

Peningkatan produk interior ini bertujuan untuk memindahkan (transfer) ilmu dan kreatifitas dalam menghasilkan produk-produk arsitektur dan interior yang lebih berkembang. Terbatas pada proses pembuatan desain ataupun finishing. Metode pelaksanaan yang akan digunakan dalam Program Kemitraan Masyarakat (PKM) untuk menemukan solusi adalah dari segi produksi dan keterbatasan desain maupun finishing dalam pembuatan kerajinan rotan dengan kegiatan sosialisasi dan pelatihan. Dan dari segi pemasaran dengan pembuatan media sosial untuk membantu promosi dan pemasaran dan kerajinan rotan kemudian dilanjutkan dengan pengarahan penggunaan media sosial untuk pemasaran.

Metode pendekatan yang digunakan untuk mengatasi persoalan yang dihadapi pihak mitra adalah pendekatan partisipasi aktif secara berkelanjutan antara tim pengabdian kepada masyarakat dengan UKM Kerajinan rotan. Penambahan Ilmu dan Teknologi yang benar serta pembinaan SDM yang baik akan memberikan inovasi karya yang sempurna, menghasilkan bentuk produk yang kuat dan mutu yang baik. Pemecahan masalah dalam rangka peningkatan disegala aspek yang ditawarkan dengan skala prioritas dalam rencana kegiatan (Putra, Fatkhurohman, \& Soebiyakto, 2018). Adapun bentuk partisipasi mitra dalam pelaksanaan PKM adalah menyediakan perlengkapan pelatihan, mendampingi dalam proses sosialisasi, memberikan ide/gagasan model workshop dan desain kerajinan, pendampingan dan penilaian atas capaian program yang dilaksanakan tim pengabdian terhadap pelaku ukm dan aktif berinovasi baik dalam pengembangan maupun pemasaran produk kerajinan rotan yang dilakukan secara langsung maupun media sosial.

Metode pertama yang digunakan adalah metode presentasi. Metode ini dilaksanakan pada tanggal 11 Oktober 2019 digunakan untuk menyampaikan hal-hal yang berkaitan dengan perkembangan dan potensi peningkatan mutu kerajinan rotan, contoh-contoh perkembangan produk kerajinan rotan, alat dan bahan yang akan digunakan, serta tahapan-tahapan membuat produk. Presentasi dilengkapi dengan narasi deskriptif, gambar-gambar, serta video yang dikemas sedemikian rupa sehingga menarik dan mudah dimengerti oleh peserta pelatihan. Metode kedua dilaksanakan pada tanggal 12 Oktober 2019 adalah metode demonstrasi. Metode ini bertujuan untuk menunjukkan proses atau bagaimana cara meningkatkan mutu kerajinan. Dimulai dengan menentukan model, menyiapkan alat dan bahan, proses pembuatan, hingga sentuhan akhir (finishing touch). Metode

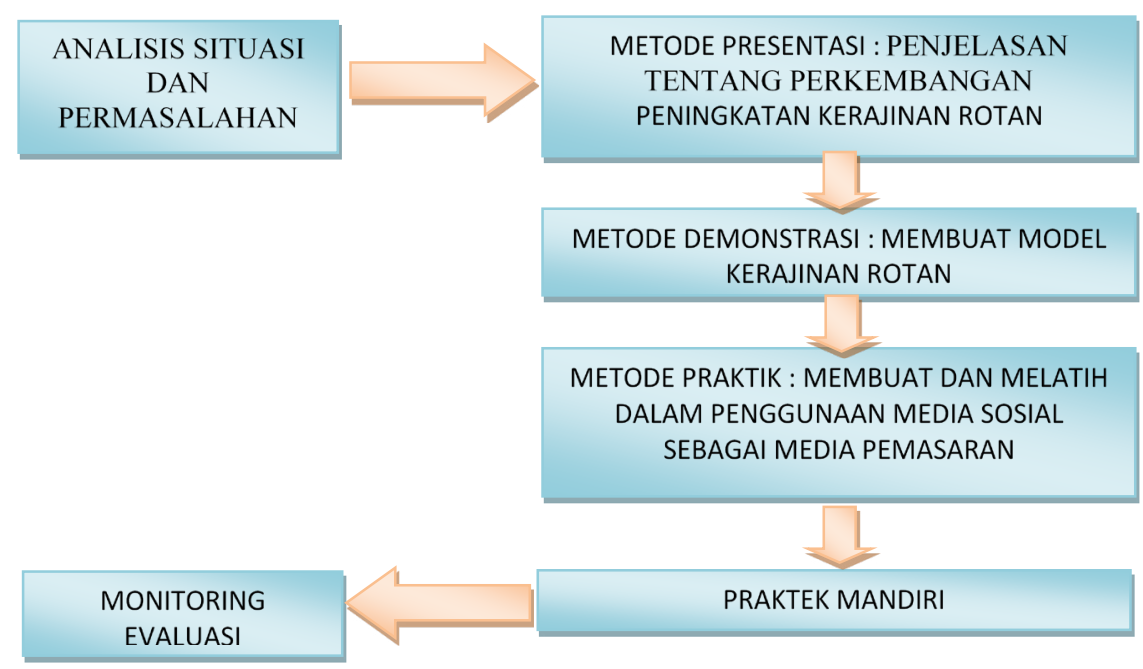

Gambar 1. Skema Metode pelaksanaan 
ketiga dilaksanakan pada tanggal 13 Oktober 2019 adalah metode praktik, Metode ini dilakukan untuk melatih peserta pelatihan dalam membuat dan memasarkan produk kerajinan rotan yang mereka buat. Metode ini dilakukan agar peserta pelatihan tersebut mempunyai pengalaman langsung dalam memasarkan hasil kerajinan mereka.

Secara skematis, metode pelaksanaan pelatihan dapat digambarkan sebagaimana gambar 1.

Fungsi perguruan tinggi disini adalah untuk dapat meningkatkan kualitas dan kuantitas hasil usahanya, ditinjau dari proses pemilihan bahan,desain,pembuatan dan pemasaran. Penambahan Ilmu dan Teknologi yang benar serta pembinaan SDM yang baik akan memberikan inovasi karya yang sempurna, menghasilkan bentuk produk yang kuat dan kwalitas mutu yang baik (Putra, Fatkhurohman, \& Soebiyakto, 2017). Juga dilakukan monitoring dengan kunjungan lapangan dengan melihat hasil pelatihan yang diterapkan dan juga melakukan monitoring keterampilan anggota kelompok pada media sosial pemasaran digital. Pada saat pemantauan dilakukan kembali upaya-upaya yang bisa menumbuhkan kreatifitas dan keahlian sumber daya yang ada untuk mengembangkan usahanya secara jangka panjang dan realisasi perencanaan jangka panjang untuk peningkatan produksi dan kapasitas setelah melakukan pelatihan. Sedangkan untuk bentuk evaluasi dilakukan pada segi peningkatan desain kerajinan rotan yang telah dibuat dan dari segi pemasaran pada media sosial.

\section{HASIL DAN PEMBAHASAN}

Pelaksanaan Pengabdian ini pada tanggal 11-13 Oktober 2019 dan lokasi Pengabdian ini berada di UKM Kerajinan Rotan yang secara administratif terletak di Jalan Rappocini Lorong 5 RT 02 RW 04 Kelurahan Rappocini Kecamatan Rappocini Kota Makassar. UKM Kerajinan Rotan ini menerima jasa pembuatan produk interior seperti kursi, meja, ayunan bayi, dan lain sebagainya yang berbahan baku rotan. Mereka juga menerima reparasi untuk perbaikan dari kerajinan rotan yang sudah rusak mulai dari mengganti anyaman maupun dari segi finishing. UKM Kerajinan Rotan ini berdiri sejak tahun 2000, yang awalnya memulai usaha sendiri oleh Bapak Alex kemudian mengajari dan memperkerjakan pegawai 4 orang dari yang membuat rangka hingga menganyam rotan sehingga UKM kerajinan rotan ini mulai bisa menerima pesanan dalam jumlah banyak.

Sasaran pengabdian ini diharapkan terlihat jelas perubahan dalam aspek desain UKM Kerajinan Rotan dan dari segi pemasaran. Namun, hasil akhir pengabdian diupayakan tetap memberi kesan asli dari rotan. Selanjutnya melihat dan mengamati desain dan model apa yang berkembang saat ini dari penggunan rotan sebagai pengembangan produk interior. Kami pun memberikan sedikit ilmu tentang Kewirausahaan. Penekanan Kewirausahaan yang memiliki tujuan khusus ke arah kewirausahaan yang mengolah skill dan kemampuan yang dibutuhkan untuk memulai dan mengatur suatu bisnis dengan sukses. Strategi-strategi yang efektif yang dapat digunakan perusahaan kecil untuk berkompetisi dengan toko-toko besar dan perusahaan besar (Longenecker, Moore, \& Petty, 2001).

Dari segi produksi dan keterbatasan desain maupun finishing dalam pembuatan kerajinan rotan dengan kegiatan Sosialisasi dan Pelatihan. Pelatihan yang dilakukan mengenai tata cara peningkatan desain maupun finishing dari kerajinan rotan. Pelatihan ini dilakukan bersama pelaku UKM dengan pemateri yang langsung memberikan penjelasan tentang rotan dan Bagaimana mengembangkan desain untuk produk interior kerajinan rotan. Berdiskusi antara tim pelaksana dan mitra tentang solusi dari permasalahan yang ada. Mengumpulkan referensi tentang proses teknologi yang berbahan baku: rotan, besi atau aluminium, pengetahuan tentang proses pemotongan (cutting) material dan pengelasan (welding) material yang baik dan inovasi teknologi sehingga dapat menghasil sesuatu barang produksi yang bernilai seni tinggi dan di minati oleh masyarakat.

Dalam Pelatihan ini kami membagikan modul dan menampilkan slide agar Sumber Daya Manusia pada UKM Kerajinan Rotan ini dapat melihat jelas dan tentang pengembangan produk dari segi desain dan finishing dari kerajinan rotan yang trend sekarang ini. Kami memaparkan Peluang yang dapat mereka ambil seperti potensi desain dengan ciri khas etnis lokal, trend dari 

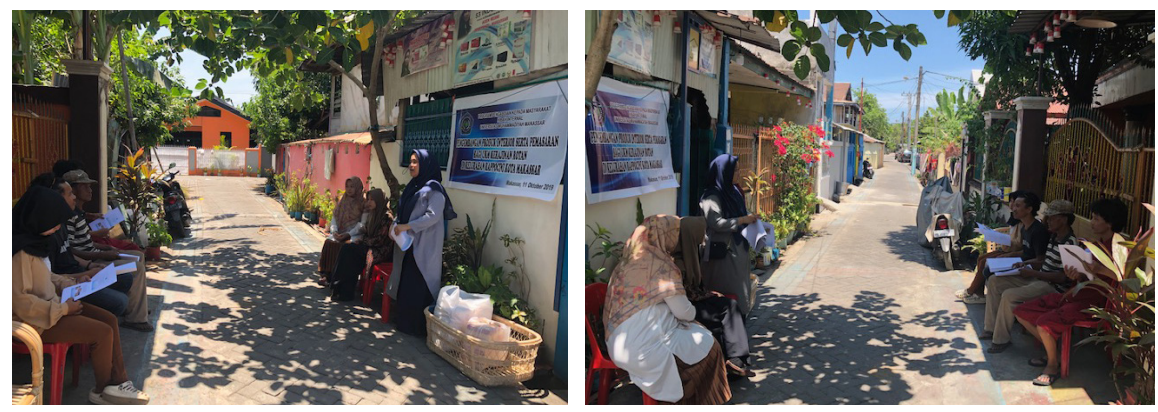

Gambar 2. Sosialisasi dan pelatihan yang dilakukan

green lifestyle yang meningkat dan juga prediksi peningkatan pasar dari furniture di dunia. Selain peluang tetap kami memberikan penjelasan tentang beberapa tantangan untuk mendapat kan peluang tersebut.

Peluang dan tantangan dalam pengembangan produk interior kerajinan rotan. Di mana peluang terbesar dari bahan baku yang besar, bahan baku rotan dapat ditemukan di Kawasan Kima dan untuk tantangan yang kami ambil yaitu belum berkembangnya Sumberdaya Manusia bidang desain. Desain yang trend sekarang seperti tema rustic yang mengedepan kan bahan alami seperti penggunaan kayu ataupun rotan. Dari segi desain kita melihat banyak model desain yang bisa kita terapkan dalam peningkatan desain. Kemudian menggabungkan material selain rotan seperti penggunaan kaki besi maupun penggunaan bantalan kursi.
Finishing dengan menggunakan warna alami ataupun penggunaan cat berwarna selain warna alami dari rotan. Finishing yang dapat dilakukan meliputi Natural Coating cara yang paling sering dilakukan adalah kursi rotan diamplas dan diberi sanding sealer kemudian diberikan pelapis akhir dengan menggunakan clear coating (cat transparan). Finishing ini membuat serat-serat rotan akan tampak lebih alami. Warna rotan yang dihasilkan yaitu putih kekuningan atau kuning kecoklatan akan memberikan kesan natural. Ataupun dengan finishing Dancy Colour adalah pengecatan yang dapat menciptakan efek unik pada hasil finishing kerajinan rotan untuk interior maupun eksterior. Finishing ini termasuk dalam kelompok fancy sealer yang memberikan efek warna pastel pada kerajinan rotan. Selain peluang tetap kami memberikan penjelasan tentang beberapa tantangan untuk mendapatkan peluang tersebut.
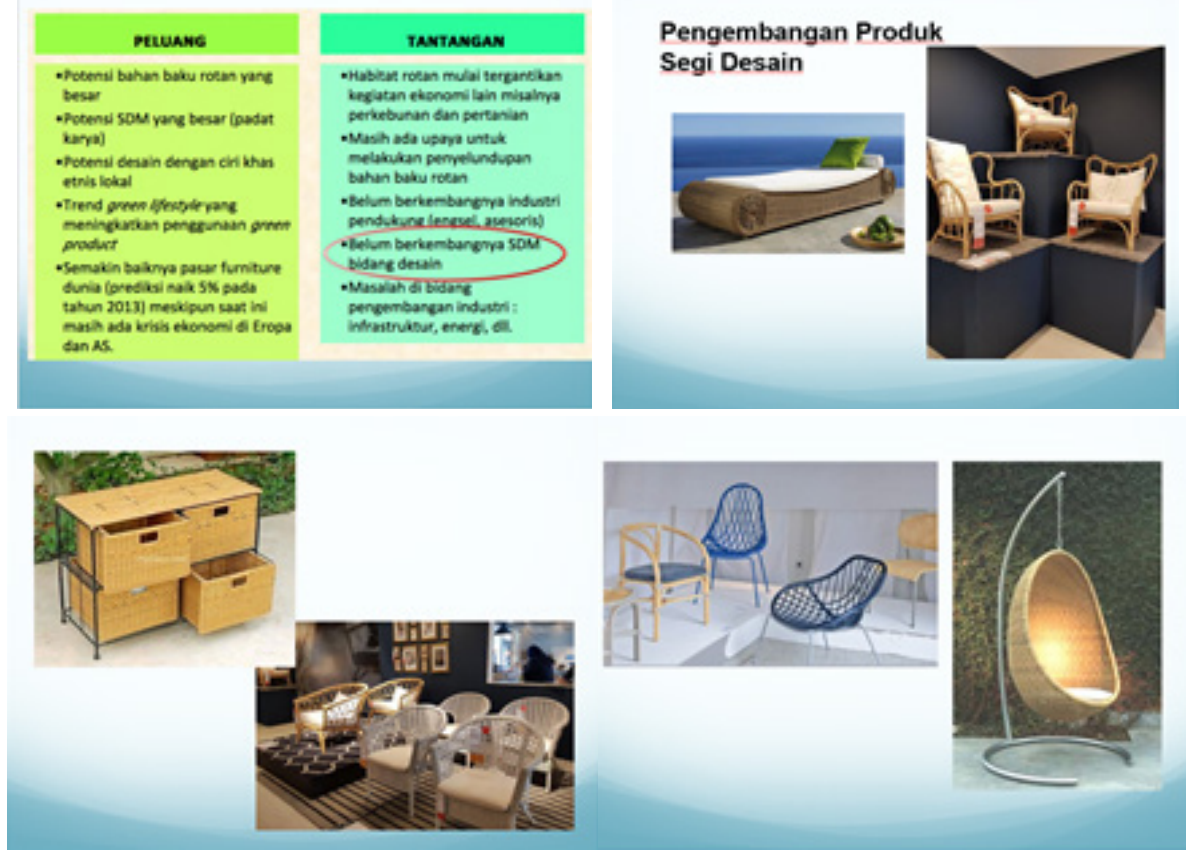

Gambar 3. Materi slide dan desain kerajinan yang berkembang saat ini 
Dapat dilihat pada gambar dibawah beberapa meteri dari slide maupun modul yang mereka dapat terapkan pada produk interior kerajinan rotan yang mereka buat.

Pengembangan desain produk interior kerajinan rotan yang ada sekarang dengan model yang lebih aktraktif tidak monoton dengan penggabungam material lain selain rotan seperti besi pada kaki kursi ataupun produk interior lainnya ,penambahan alas kursi yang serasi dengan warna maupun bentuk dari produk yang dihasilkan dan finishing pemakaian cat varnish untuk memberikan warna dasar rotan lebih menarik ataupun warna lain selain warna rotan seperti putih maupun warna lainnya. Setelah pelatihan, pelaku UKM rotan ini mulai mengaplikasikan. Di mana kami melihat dan memberikan pengarahan sesuai dengan ilmu yang kami miliki dari segi desain dan finishing dari produk ukm rotan. Dalam pengarahan ini kami perlihatkan trend yang sedang berkembang dari segi desain, bentuk, ukuran, tema hingga warna yang sedang trend. Hal ini kami lakukan agar memberikan peningkatan dari produk kerajinan rotan yang dihasilkan sehingga dari segi omzet pun meningkat.

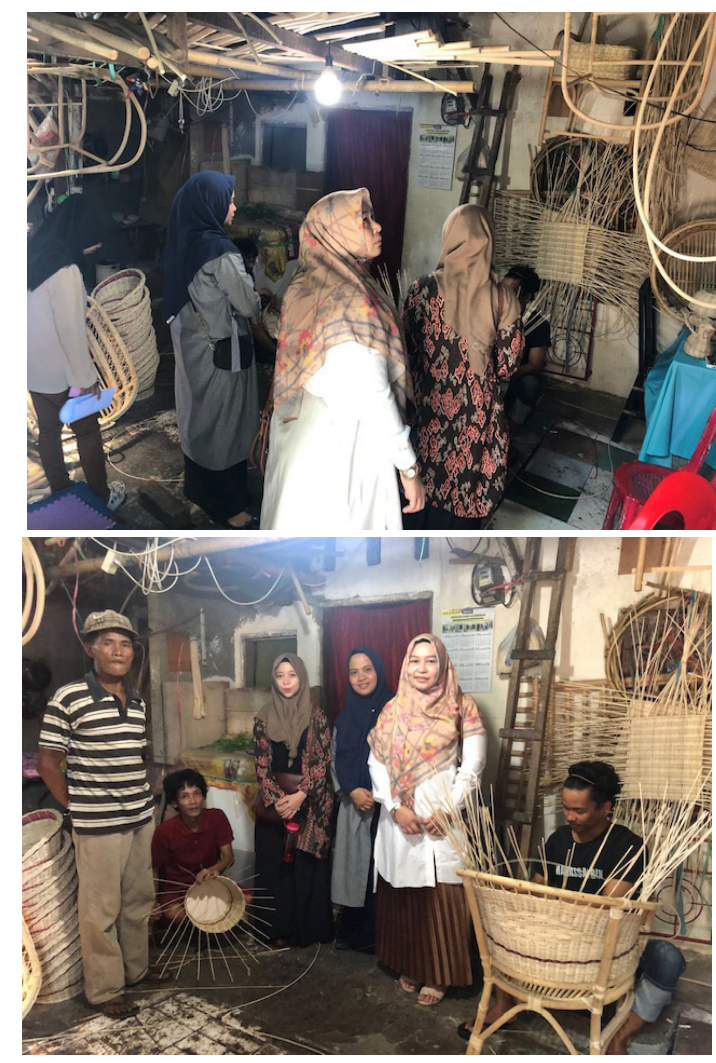

Gambar 4. Pengaplikasian dan pengarahan
Dari segi pemasaran dengan pembuatan media social untuk membantu promosi dan pemasaran dan kerajinan rotan kemudian dilanjutkan dengan pengarahan penggunaan media sosial untuk pemasaran. Dalam pengabdian ini kami membantu UKM dalam pembuatan media sosial untuk mempermudah pemasaran seperti yang sedang trend saat ini. Media sosial ini akan mereka update dan masukkan beberapa foto hasil maupun pesanan yang tengah dibuat maupun yang sudah selesai. Pengarahan penggunaan media sosial ini kami lakukan agar apa yang mereka tidak mengerti lebih jela mereka pahami dari segi pemasaran. Sehingga pemasaran bisa dapat menjangkau hingga keluar daerah dengan penggunaan media sosial yang ada. Dalam segi pemasaran UKM Kerajinan Rotan ini pun perlu membuat rencana pemasaran (marketing plan) yang tepat sasaran agar lebih baik kedepannya. UKM Kerajinan Rotan ini pun perlu mengikuti pameranpameran yang diadakan di Kota Makassar dan dapat mendaftarkan merk dagang dari kerajinan rotan yang diproduksinya seperti membuat nama merk dagang produksi mereka sendiri.

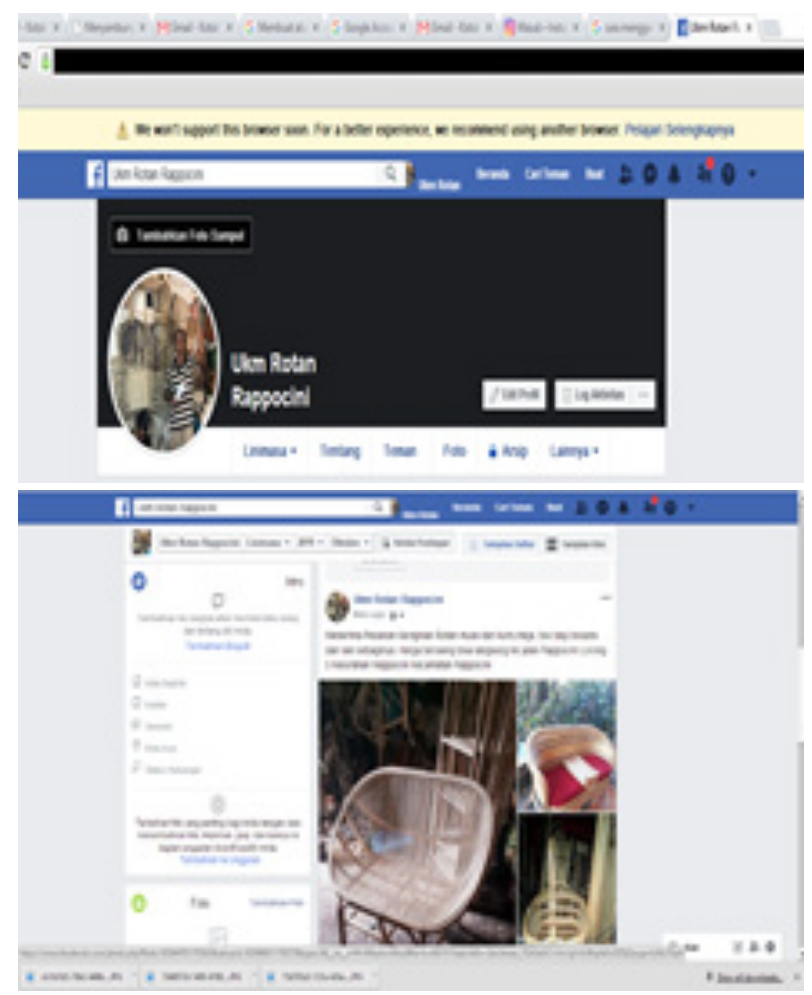

Gambar 5. Salah satu media sosial untuk pemasaran 
Setelah kegiatan pelatihan tentang peningkatan desain maupun finishing dari kerajinan rotan. maka tahapan yang selanjutnya adalah pemantauan kegiatan yang dilakukan oleh Kelompok pengabdian ini kepada mitra UKM kerajinan rotan adalah Apakah mitra pengabdian semakin bersemangat dalam meningkatkan desain dari kerajinan rotan. Apakah praktik dari pelatihan peningkatan desain maupun finishing diterapkan untuk lebih mengembangkan usaha kerajinan rotan dan menambah pendapatan bagi UKM Kerajinan Rotan. Apakah Media Sosial sebagai media pemasaran telah digunakan untuk meningkatkan pendapatan mitra.

\section{SIMPULAN}

Dari hasil kegiatan pengabdian tersebut dapat disimpulkan bahwa secara sederhana ilmu arsitektural dapat kita terapkan dengan cara melihat banyak referensi desain kerajinan yang sedang trend sekarang dengan begitu untuk hasil yang dicapai dapat menghasilkan peningkatan omzet pada mitra yang bergerak dalam bidang ekonomi, UKM pengrajin rotan sudah dapat terlihat kesunguhannya dalam menerima masukan berupa ilmu-ilmu untuk meningkatkan pengembangan desain dari kerajinan rotan yang akan dibuat ke depannya. Pelaku UKM Kerajinan rotan ini dengan semangat untuk memenuhi pembuatan produkyang bermutu tinggi sehingga produk hasil lebih baik. Peningkatan kuantitas dan kualitas produk, Peningkatan pemahaman dan keterampilan, Peningkatan ketentraman masyarakat (mitra masyarakat umum) dan juga peningkatan jasa, model, rekayasa sosial, system, produk/barang. Selain hal itu kegiatan pengabdian ini menambahkan wawasan material lain maupun elemen dekoratif dari segi finishing maupun penggunaan bantal maupun alas kursi pada kerajinan rotan.

Saran dalam kegiatan pengabdian masyarakat ini antara lain demi pengembangan produk interior pada kerajinan rotan ini berkesinambungan, dibutuhkan evaluasi secara berkala seperti kunjungan pelaksana kegiatan pengabdian dan pihak pelaku UKM rotan sendiri. Evaluasi berupa pelaporan kondisi pengembangan produk yang dapat menjadi referensi kegiatan serupa selanjutnya dan juga sebagai media silaturahmi antara kedua pihak. Juga diperlukannya peran pemerintah yang terkait yaitu pemerintah daerah atau departemen perdagangan dalam segi pemasaran perlu membuat pembuatan rencana pemasaran (marketing plan) yang tepat sasaran untuk UKM khususnya UKM Kerajinan Rotan ini agar lebih baik ke depannya. Pemerintah terkait ini pun perlu mengikutkan UKM Kerajinan Rotan yang ada untuk ikut andil dalam pameran-pameran yang diadakan baik di dalam Kota maupun di luar kota dan dapat mendaftarkan merk dagang dari kerajinan rotan yang diproduksinya.

\section{UCAPAN TERIMA KASIH}

Puji syukur penulis panjatkan kehadiran Allah SWT, atas karunia yang dilimpahkan, sehingga pelaksanaan kegiatan pengabdian masyarakat yang berjudul "Pengembangan Produk Interior dan Pemasaran bagi UKM Kerajinan Rotan di Kelurahan Rappocini Kecamatan Rappocini Kota Makassar" telah selesai dan dapat terlaksana dengan baik juga lancar. Terselenggaranya kegiatan pengabdian masyarakat ini berkat kerjasama dan dukungan berbagai pihak, sehingga melalui laporan ini kami menyampaikan ucapan terima kasih kepada LP3M Universitas Muhammadiyah Makassar yang memberikan dana internal dari Universitas Muhammadiyah Makassar guna terlaksananya kegiatan pengabdian kepada masyarakat ini, Kelompok Pengabdian Kepada Masyarakat yang selalu kompak dalam melaksanakan kegiatan ini, UKM Kerajinan Rotan di Kelurahan Rappocini yang mau menjalin kerjasama dan selalu bersemangat dalam mengikuti tahapan-tahapan dalam kegiatan pengabdian ini dan semua pihak yang tidak bisa kami sebutkan satu persatu. Akhir kata, kami dari kelompok pengabdian kepada masyarakat berharap semoga hasil kegiatan pengabdian ini bermanfaat bagi pengembangan pengetahuan serta meningkatkan Pengembangan Produk Interior dan Pemasaran bagi UKM Kerajinan Rotan khususnya kelurahan Rappocini Kecamatan Rappocini Kota Makassar lebih baik lagi kedepannya dan dapat menjadi tolak ukur untuk pengembangan UKM Kerajinan Rotan yang lainnya. 


\section{DAFTAR PUSTAKA}

Badan Pusat Statistik Kota Makassar. (2019). Kecamatan Rappocini Dalam Angka. Makassar: BPS Kota Makassar.

Departemen Perdagangan. (2008). Pengembangan Industri Pengolahan Rotan Indonesia. Jakarta: Biro Umum dan Humas.

Wati, E. E. (2011). Persepsi Para Pelaku UKM (Usaha Kecil dan menengah) terhadap Penerapan Akuntansi. Skripsi. Sekolah Tinggi Ilmu Ekonomi Perbanas Surabaya.

Candra, G., R., Darmastuti,R., (2019). Strategi Komunikasi Pengusaha Rotan Dalam Rangka Membangkitkan Industri Rotan di daerah Trangsan. Jurnal Komunikasi Universitas Garut, 5(1),118-134. http://dx.doi.org/10.10358/jk.v5i1.587

Longenecker, J. G., Moore, C. W., Petty, J. W. (2001). Kewirausahaan Manajemen Usaha Kecil. Jakarta: Salemba Empat.

Kementerian Perindustrian RI. (2019, November 1) Pengembangan Industri Pengolahan Rotan Indonesia. Diakses dari http://www.kemenperin.go.id

Kuswantoro,F., Rosli,M.M., Kader,R. A., (2012). Innovation in Distribution Channel, Cost Efficiency \& Firm Performance: The Case of Indonesian Small \& Medium Enterprise Scales. International Journal of Business, Humanities and Technology, 2 (4), 23-38

Muhartini, Muani,A., Kurniati, D. (2013). Optimasi Produk Kerajinan Rotan pada Industri Kecil Menengah (IKM) Dangau Daik di Desa Pandu Raya Kecamatan Kapuas Kabupaten Sanggau. Jurnal Sains Mahasiswa Untan, 2 (3), 1-12

Putra, T. D., Fatkhurohman, F., Soebiyakto, G. (2017). Kerajinan Rotan dan Bahan Sintetis di Kelurahan Balearjosari Kecamatan Blimbing Kota Malang. JPM (Jurnal Pemberdayaan Masyarakat), 2(2), 158-165. https://doi.org/10.21067/jpm.v2i2.2060

Putra, T. D., Fatkhurohman, F., Budiantono, B. (2018). Peningkatan Mutu Produk Kerajinan Rotan dengan Sentuhan Teknologi Kota Malang. Procedding Conference on Innovation and Application of Science and Tehnology (CIASTECH) 